\title{
Origin-related differences in plumage coloration within an island population of great tits (Parus major)
}

\author{
Postma, E ; Gienapp, P
}

\begin{abstract}
Several studies have described geographic variation in plumage coloration, providing important insights into the processes of local adaptation and speciation. Given that such variation appears to be common, individuals of different origin within a single population may vary accordingly. However, as yet no study has been able to test for such origin-related differences. The population of great tits (Parus major L., 1758) on the small Dutch island of Vlieland is especially suitable for such a study, as we know of every breeding adult whether it has been born on the island or not, and if it is, where on the island it was born. Furthermore, we have previously found large differences in clutch size and survival among birds of different origin in the same population. Here, we measured the spectral reflectance of the yellow breast feathers, and found that yearling, but not older, birds born in the eastern part of the island had feathers that were of a less bright yellow and UV than birds born elsewhere, irrespective of where they were breeding. Interestingly, this difference in coloration among yearlings of different origin shows a remarkable similarity with the genetic differences found earlier in this population with respect to clutch size and local survival. We thus show that systematic differences in color signals may exist within populations, among individuals of different origin, and we argue that it is crucial that such variation and its potential implications be accounted for irrespective of whether these differences have a genetic or an environmental basis. De nombreuses études ont décrit la variation géographique de la coloration du plumage et ainsi ouvert des perspectives importantes sur les processus d'adaptation locale et de spéciation. Comme ce type de variation semble être commun, les individus d'origine différente dans une même population peuvent varier en conséquence. Cependant, à ce jour, aucune étude n'a réussi à tester ces différences reliées à l'origine. La population de mésanges charbonnières (Parus major L., 1758), de la petite île hollandaise de Vlieland convient particulièrement à une telle étude, car on sait, au sujet de chaque adulte reproducteur, s'il est né ou non sur l'île et, si oui, on connaît l'endroit de sa naissance sur l'île. De plus, nous avons trouvé antérieurement de fortes différences dans les tailles des couvées et la survie parmi les oiseaux d'origines diverses dans cette même population. Nous mesurons ici la réflectance spectrale des plumes jaunes de la poitrine et observons que les oiseaux d'un an, mais non les plus âgés, nés dans la partie orientale de l'île ont des plumes de coloration jaune et UV moins vive que les oiseaux nés ailleurs, quel que soit l'endroit où ils se reproduisent. Ce qui est intéressant, c'est que les différences de coloration chez les jeunes d'un an d'origines différentes sont remarquablement similaires aux différences génétiques trouvées antérieurement dans cette population, en ce qui a trait à la taille des couvées et à la survie locale. Nous démontrons donc qu'il peut exister des différences systématiques dans les signaux de coloration dans les populations, parmi les individus d'origines différentes; nous croyons qu'il est essentiel de tenir compte de cette variation et de ses conséquences potentielles, que ces différences aient une base génétique ou environnementale.
\end{abstract}

DOI: https://doi.org/10.1139/Z08-132 
ZORA URL: https://doi.org/10.5167/uzh-18136

Journal Article

Originally published at:

Postma, E; Gienapp, P (2009). Origin-related differences in plumage coloration within an island population of great tits (Parus major). Canadian Journal of Zoology, 87(1):1-7.

DOI: https://doi.org/10.1139/Z08-132 


\title{
Origin-related differences in plumage coloration within an island population of great tits (Parus major)
}

\author{
E. Postma and P. Gienapp
}

\begin{abstract}
Several studies have described geographic variation in plumage coloration, providing important insights into the processes of local adaptation and speciation. Given that such variation appears to be common, individuals of different origin within a single population may vary accordingly. However, as yet no study has been able to test for such originrelated differences. The population of great tits (Parus major L., 1758) on the small Dutch island of Vlieland is especially suitable for such a study, as we know of every breeding adult whether it has been born on the island or not, and if it is, where on the island it was born. Furthermore, we have previously found large differences in clutch size and survival among birds of different origin in the same population. Here, we measured the spectral reflectance of the yellow breast feathers, and found that yearling, but not older, birds born in the eastern part of the island had feathers that were of a less bright yellow and UV than birds born elsewhere, irrespective of where they were breeding. Interestingly, this difference in coloration among yearlings of different origin shows a remarkable similarity with the genetic differences found earlier in this population with respect to clutch size and local survival. We thus show that systematic differences in color signals may exist within populations, among individuals of different origin, and we argue that it is crucial that such variation and its potential implications be accounted for irrespective of whether these differences have a genetic or an environmental basis.

Résumé : De nombreuses études ont décrit la variation géographique de la coloration du plumage et ainsi ouvert des perspectives importantes sur les processus d'adaptation locale et de spéciation. Comme ce type de variation semble être commun, les individus d'origine différente dans une même population peuvent varier en conséquence. Cependant, à ce jour, aucune étude n'a réussi à tester ces différences reliées à l'origine. La population de mésanges charbonnières (Parus major L., 1758), de la petite île hollandaise de Vlieland convient particulièrement à une telle étude, car on sait, au sujet de chaque adulte reproducteur, s'il est né ou non sur l'île et, si oui, on connaît l'endroit de sa naissance sur l'île. De plus, nous avons trouvé antérieurement de fortes différences dans les tailles des couvées et la survie parmi les oiseaux d'origines diverses dans cette même population. Nous mesurons ici la réflectance spectrale des plumes jaunes de la poitrine et observons que les oiseaux d'un an, mais non les plus âgés, nés dans la partie orientale de l'île ont des plumes de coloration jaune et UV moins vive que les oiseaux nés ailleurs, quel que soit l'endroit où ils se reproduisent. Ce qui est intéressant, c'est que les différences de coloration chez les jeunes d'un an d'origines différentes sont remarquablement similaires aux différences génétiques trouvées antérieurement dans cette population, en ce qui a trait à la taille des couvées et à la survie locale. Nous démontrons donc qu'il peut exister des différences systématiques dans les signaux de coloration dans les populations, parmi les individus d'origines différentes; nous croyons qu'il est essentiel de tenir compte de cette variation et de ses conséquences potentielles, que ces différences aient une base génétique ou environnementale.
\end{abstract}

[Traduit par la Rédaction]

\section{Introduction}

Given its central role in sexual selection (Andersson 1994), intraspecific variation in coloration has attracted a

Received 14 February 2008. Accepted 23 October 2008.

Published on the NRC Research Press Web site at cjz.nrc.ca on 12 December 2008.

E. Postma ${ }^{1,2}$ and P. Gienapp. ${ }^{3}$ Netherlands Institute of Ecology (NIOO-KNAW), Centre for Terrestrial Ecology, P.O. Box 40, 6666 ZG Heteren, the Netherlands.

${ }^{1}$ Corresponding author (e-mail: e.postma@access.uzh.ch). ${ }^{2}$ Present address: Zoological Museum, University of Zürich, Winterthurerstrasse 190, 8057 Zürich, Switzerland.

${ }^{3}$ Present address: Department of Biological and Environmental Sciences, University of Helsinki, P.O. Box 65, Viikinkaari 1, 00014 Helsinki, Finland. great amount of interest in a wide range of taxa (e.g., Houde 1987; Milinski and Bakker 1990; Olsson 1994; Sinervo and Lively 1996; Kodric-Brown and Johnson 2002; Hill and McCraw 2006). Although the vast majority of these focused solely on variation among individuals within a single population, numerous studies have by now described differences in coloration among populations of insects (e.g., Abbott et al. 2008), fish (e.g., Houde and Endler 1990; Grether et al. 1999), mammals (e.g., Hoekstra et al. 2005), reptiles (e.g., Stuart-Fox et al. 2004; Rosenblum 2006), and many species of birds (e.g., Slagsvold and Lifjeld 1985; Bensch et al. 1999; Hõrak et al. 2001; Doucet et al. 2004). Given that differences in coloration among populations are common and exist across a range of geographical scales, individuals of different origin within a single population may also differ accordingly. However, even though many studies have described variation across a range of geographical scales, 
none have so far compared individuals of different origin within a single population. However, irrespective of whether such systematic phenotypic differences have a genetic or an environmental basis, when individuals of different origin vary in more ways than just their color (e.g., fitness or mate-choice preferences) and we do not account for these differences explicitly, this can easily lead to the incorrect inference of, among others, selection or assortative mating.

In birds we can distinguish two types of (plumage) coloration, namely those that are pigment-based and those that are structural. An example of the first are the yellow and bright red colors seen in many species, which are typically based on carotenoid pigments deposited in the feathers (see, for example, Table 5.1 in McGraw 2006). Birds are unable to synthesize carotenoids themselves and thus have to obtain them from the environment (Goodwin 1984), but there their availability is limited (e.g., Grether et al. 1999; Tschirren et al. 2003). As carotenoids are not only used for coloration, but also play an important role in many physiological processes (Olson and Owens 1998), variation in carotenoid-based coloration is often considered to be a reliable predictor of individual quality. For example, individuals with plumage that contains more carotenoids are healthier (e.g., Hõrak et al. 2001; Saks et al. 2003b), survive better (Hill 1991; Hõrak et al. 2001), are in better nutritional condition (Hill and Montgomerie 1994), or provide more care for their young (Senar et al. 2002).

Variation in carotenoid-based coloration among populations may reflect variation in carotenoid availability in the environment, which may be mediated directly via the carotenoid content of the food or indirectly via the carotenoid content of the eggs (e.g., Slagsvold and Lifjeld 1985; Hõrak et al. 2001; Biard et al. 2006, 2007). Alternatively, birds of different origin may differ in their ability to incorporate the available carotenoids into their feathers, or in the relative amount of carotenoids allocated to plumage and, for example, the immune system. This may have a genetic basis, but also may be the result of (early) environmental conditions (Hill and Montgomerie 1994; Hõrak et al. 2000, 2001; Fitze et al. 2003; Hadfield and Owens 2006).

Of the few studies that have compared carotenoid-based color expression in birds from different habitats and (or) populations, most focused on nestling plumage coloration. Slagsvold and Lifjeld (1985) found that nestlings of great tits (Parus major L., 1758) in deciduous forest were more intensely yellow than those reared in coniferous forest, and Eeva et al. (1998) found that nestling great tits living farther away from a polluting copper smelter had more intense yellow breast feathers. Furthermore, Arriero and Fargallo (2006) found reduced expression of carotenoid-based coloration in nestling blue tits (Cyanistes caeruleus (L., 1758)) growing up in young and structurally simple forests. Finally, Hõrak et al. $(2000,2001)$ found that both fledgling and adult great tits in a rural area were more yellow than those from an urban area.

Carotenoid content of feathers has been found to explain a significant and substantial proportion of the variation in the yellowness of, for example, tail feathers of European greenfinches (Carduelis chloris (L., 1758) (Saks et al. 2003a). However, a substantial amount of variation in yellow coloration may in fact be attributable to other sources like the underlying microstructure of the feather (Shawkey and Hill 2005). Interestingly, this microstructure reflects in the UV part of the spectrum as well (between 320 and $400 \mathrm{~nm}$ ) (Eaton and Lanyon 2003; Prum et al. 2003), which birds and many other animals are able to see (Bennett and Cuthill 1994).

The production and maintenance of this regular microstructure is likely to be costly. Not only is it sensitive to developmental stress, but it is also affected by external factors like, for example, feather abrasion, the accumulation of dirt, and the presence of feather-degrading bacteria (e.g., Örnborg et al. 2002; Shawkey et al. 2007). UV coloration is thus, just like carotenoid-based coloration, assumed to reflect phenotypic quality (Keyser and Hill 2000). Both types of coloration are, however, likely to differ in their information content (Candolin 2003; Johnsen et al. 2003), although as yet we know very little about how birds value these fundamentally different components of plumage coloration (Saks et al. 2003a; Shawkey and Hill 2005).

Here we test for differences in adult plumage coloration across the full bird-visible spectrum among birds of different origin within the same population. We measured the spectral reflectance of yellow breast feathers of both male and female great tits of known origin, breeding in one of the two subpopulations on the small Dutch island of Vlieland. Interestingly, we have previously found large genetic differences in clutch size and survival, both between birds born in different parts of this small island, and between locally born and immigrant birds (Postma and van Noordwijk 2005). However, as yet it remains unclear whether there is a causal relationship between larger clutches and lower survival of immigrants.

Although birds of different origin do not differ in tarsus length, body mass, or wing length, it is important to keep in mind that such morphological measurements provide a very limited description of a bird, and birds may very well be different in ways that may be less obvious to the human eye, but that are by no means less important. Hence we do not only test whether birds of different origin show differences in plumage coloration, but also compare them with the previously found differences in clutch size and survival. Finally, we briefly discuss the potential evolutionary implications of small-scale geographic variation in plumage coloration for the information content of color signals, and its consequences for sexual selection in general.

\section{Materials and methods}

\section{Study population}

Vlieland is one of the smaller islands in the Dutch part of the Wadden Sea $\left(53.17^{\circ} \mathrm{N}, 5.03^{\circ} \mathrm{E} ; 3258\right.$ ha) (Fig. 1). The first nest boxes were put up in 1955, and the population has been monitored continuously since. Nest boxes are supplied and monitored in five more or less spatially separated woodlands (in total covering ca. 300 ha) and a small village. These areas can be grouped into an eastern subpopulation and a western subpopulation (van Noordwijk et al. 1981; Postma and van Noordwijk 2005). Although the woodlands in the west are younger than the woodland in the east, there are overall no obvious differences in forest composition and structure among the west and the east, whereas variation in 
Fig. 1. Map of the Netherlands (inset) with the location of the island of Vlieland (see arrow), and a detailed map of Vlieland with the location of the woodlands that provide suitable nesting habitat for great tits (Parus major) in gray, and their grouping into west and east.

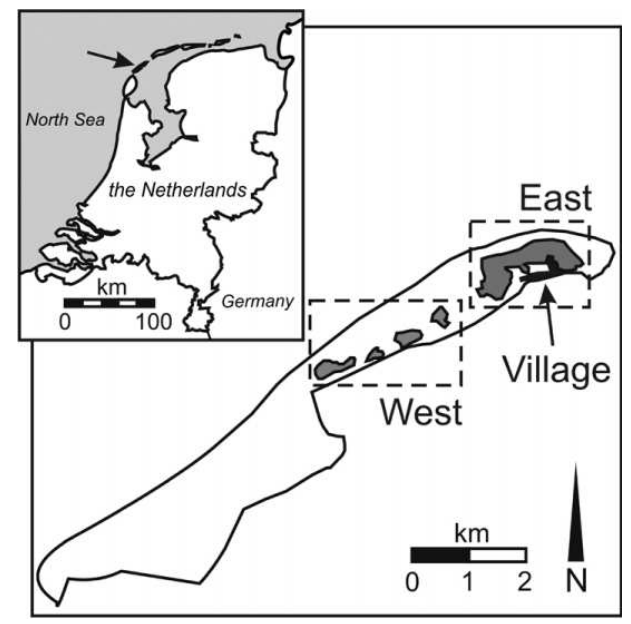

composition and structure is relatively large within both areas (E. Postma, unpublished data). The landscape between the woodlands consists mainly of dunes and is unsuitable habitat for great tits.

Since nest boxes are available in excess in all suitable nesting habitat, it is possible to ring virtually all chicks that are born on the island each year. Consequently, we can make the assumption that birds breeding on Vlieland that were not ringed as nestlings on the island are immigrants from elsewhere (Verhulst and van Eck 1996; Postma and van Noordwijk 2005). Although the village is part of the eastern subpopulation, we chose not to pool the birds born in the village and the surrounding woodland a priori, as their environments may differ considerably (e.g., Hõrak et al. 2001).

\section{Color measurements}

During the 2004 breeding season we took four feathers from a standardized area on the breast of males and females caught during chick feeding. We collected feathers from birds breeding in both the western and the eastern subpopulations, but not from birds breeding in the village. The reflectance of the feathers (measured area approximately $1 \mathrm{~mm}^{2}$ ) across the full avian visual spectrum (300-700 nm) was measured by arranging the four feathers on top of each other, resembling the natural situation as much as possible, and mounting them on black velvet. Five replicate reflectance measurements were taken using an USB2000 spectrometer with a DH2000 deuterium-halogen light source (both from Avantes, Eerbeek, the Netherlands), illuminating and measuring perpendicular to the feathers. A WS-2 PTFE white reference tile (Avantes) was used as a standard for each measurement, while the black velvet on which the feathers were mounted was used as the dark reference. A sheath that was attached to the probe prevented ambient light from being measured and ensured that the distance between the probe and the feathers remained constant. All color measurements were performed blindly with respect to the origin of the birds. In total we obtained reflectance spec- tra for 91 males and 96 females. For sample sizes per subpopulation of birth and of breeding see Table 1 .

\section{Analysis of spectra}

Raw spectral data produced by the spectrometer software (Avasoft version 5.1 Basic; Avantes), consisting of approximately 1200 data points (the reflectance from 300 to $700 \mathrm{~nm}$ at intervals of $0.3-0.4 \mathrm{~nm}$ ), was reduced to the medians of $10 \mathrm{~nm}$ bandwidths. This resulted in 40 data points per spectrum, which were subsequently transformed into principal component (PC) scores following Cuthill et al. (1999). PC scores for replicate measurements on the same bird were subsequently averaged. Repeatabilities of the PC scores were calculated following Lessells and Boag (1987). To help in the interpretation of the PC scores, we plotted the PC coefficients against the original wavelength intervals (Cuthill et al. 1999).

\section{Statistical analysis}

The main PC scores were first analyzed using an exploratory multivariate analysis of variance (MANOVA) that included sex, age (yearling or older), origin (west, east, village, or immigrant), and area of breeding (east or west), as well as all two-way interactions. This maximal model was then simplified by a stepwise deletion of nonsignificant terms, starting with the interactions. Nonsignificant terms were removed, starting with the least significant interactions (Crawley 2007). When interactions were significant the main terms were kept in the model, irrespective of their significance.

Subsequently we analyzed the individual PCs separately using ANOVA, starting with the minimal adequate model as indicated by the MANOVA. Again we removed any nonsignificant terms, starting with the least significant. If there were significant differences among birds of different origin, whether as a main effect or in an interaction with another term, we subsequently tried to find the exact location of these differences by further model simplification, lumping together birds of different origin and testing whether this resulted in a significantly worse fit of the model. Levels were lumped based on the difference between them, starting with the most similar (Crawley 2007). All analyses were performed using $\mathrm{R}$ version 2.7.1 ( $\mathrm{R}$ Development Core Team 2008).

\section{Results}

\section{Principal component analysis}

The first three PCs explained $87.5 \%, 7.26 \%$, and $3.40 \%$ of the variation, respectively, and were highly repeatable across replicate measurements (PC1: $r=0.88$; PC2: $r=$ 0.92; PC3: $r=0.88$ ). All other PCs explained $<1 \%$ of the variation in reflectance. As we did not standardize our reflectance spectra before principal components analysis by the overall reflectance, PC1 was associated with overall brightness (Fig. 2, open circles) (correlation between PC1 and mean reflectance: $r=0.999)$. PC2 and PC3 represented variation in spectral shape. PC2 (Fig. 2, solid circles) was positively correlated with the spectral reflectance between 400 and $500 \mathrm{~nm}$, and this association was strongest around $450 \mathrm{~nm}$. This is the wavelength at which the absorbance by 
Table 1. Sample sizes per origin, breeding population, and age (yearling or older) of great tits (Parus major).

\begin{tabular}{|c|c|c|c|c|c|c|}
\hline \multirow[b]{3}{*}{ Origin } & \multicolumn{6}{|c|}{ Area of breeding } \\
\hline & \multicolumn{2}{|l|}{ West } & \multicolumn{2}{|l|}{ East } & \multicolumn{2}{|l|}{ Total } \\
\hline & Yearling & Older & Yearling & Older & Yearling & Older \\
\hline Immigrant & 13 & 4 & 15 & 16 & 28 & 20 \\
\hline West & 6 & 9 & 0 & 1 & 6 & 10 \\
\hline East & 2 & 3 & 21 & 67 & 23 & 70 \\
\hline Village & 1 & 2 & 12 & 15 & 13 & 17 \\
\hline Total & 22 & 18 & 48 & 99 & 70 & 117 \\
\hline
\end{tabular}

Fig. 2. Plot of the correlation coefficients of the first three principal components (PC) of the spectral reflectance of great tit (Parus major) breast feathers against the original wavelength intervals.

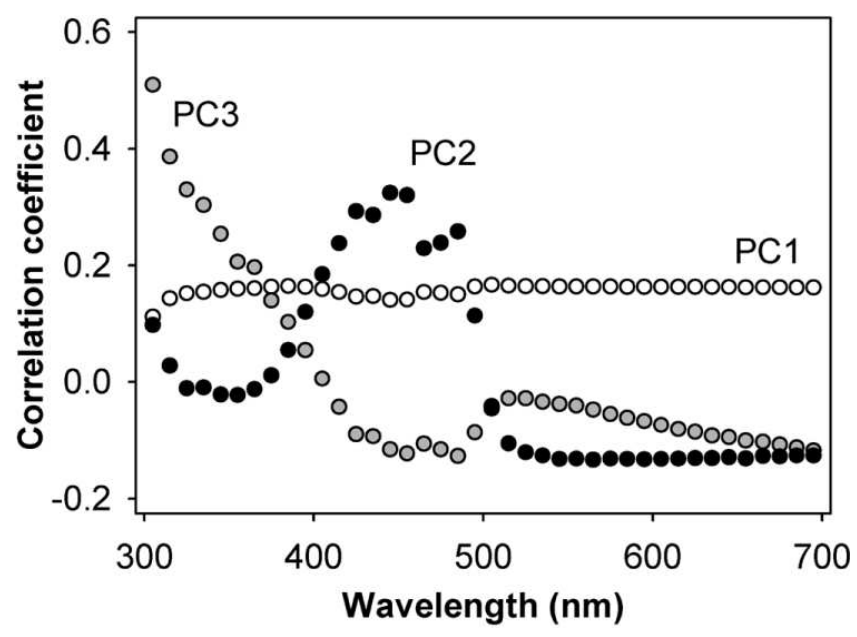

the carotenoids lutein and zeaxanthin, the pigments that give the breast feathers of great tits their yellow color, is maximal (Partali et al. 1987). Note that feathers with higher levels of carotenoids reflect less light in this part of the spectrum, and thus have lower values for PC2. Finally, PC3 (Fig. 2, shaded circles) was positively associated with variation in reflectance in the UV part of the spectrum (between 300 and $400 \mathrm{~nm}$ ). Although birds most likely do not perceive the UV and the yellow parts of the reflectance spectra of the breast feathers as two separate colors, we will refer to PC2 as reflecting variation in (carotenoid-based) yellow coloration and to PC3 as reflecting variation in (structural) UV coloration. All three PCs followed a normal distribution (Shapiro-Wilk test: $P>0.2$ ).

A MANOVA including all three PCs showed that there were significant differences in brightness and (or) spectral shape with respect to sex (Wilks' $\lambda=0.74$, exact $F_{[3,175]}=$ 20.6, $P<0.001$ ) and the area of breeding (Wilks' $\lambda=0.92$, exact $\left.F_{[3,175]}=5.34, P=0.002\right)$. Furthermore, there was a significant interaction between age and origin (Wilks' $\lambda=$ 0.89 , approximate $F_{[9,426.05]}=2.33, P=0.014$ ) (all other two-way interactions: $P>0.5)$.

\section{PC1 (overall brightness)}

Although the main focus of this paper is on chromatic variation (represented by $\mathrm{PC} 2$ and PC3, see Fig. 2), we briefly report the results for $\mathrm{PC} 1$, reflecting achromatic var- iation among individuals. Birds breeding in the east were brighter than those breeding in the west $\left(F_{[1,183]}=11.4, P<\right.$ $0.001)$, while males were brighter than females $\left(F_{[1,183]}=\right.$ $7.46, P=0.007)$ and older birds were brighter than yearlings $\left(F_{[1,183]}=5.05, P=0.026\right)$. The interaction between origin and age was not significant $\left(F_{[3,177]}=1.67, P=0.18\right)$; there was also no significant main effect of origin on PC1 $\left(F_{[3,180]}=1.00, P=0.39\right)$.

\section{PC2 (yellow)}

There was no significant difference in PC2 between birds breeding in the east and the west $\left(F_{[1,177]}=0.060, P=0.81\right)$, or between males and females $\left(F_{[1,178]}=2.21, P=0.14\right)$. However, there were differences among birds of different origin (immigrant, west, east, village), and these differences were different between yearling (so born in 2003) and older birds (born before 2003) (age $\times$ origin interaction: $F_{[3,179]}=$ 2.96, $P=0.034$ ) (Figs. 3A, 3B).

Further model simplification by lumping birds of different origin provided no evidence for a difference in $\mathrm{PC} 2$ between birds born in the east and birds born in the village $\left(F_{[2,179]}=\right.$ $0.068, P=0.93)$; there was also no difference between birds born in the west and immigrants $\left(F_{[2,181]}=0.58, P=0.56\right)$. The interaction between origin (east or village vs. west or immigrant) was, however, also highly significant in this simplified model $\left(F_{[1,183]}=8.45, P=0.004\right)$.

A pairwise post hoc comparison of yearling and adult birds from the east or the village on the one hand, and from the west and immigrant birds on the other (on the basis of Tukey's honest significant differences), showed that young eastern and village birds were significantly less yellow than young immigrant and western birds $(P<0.001)$ (Fig. 3A), while this difference did not exist among the older birds $(P=0.99)$ (Fig. 3B). Furthermore, while older western and immigrant birds did not differ from yearling birds of the same origin $(P=0.99)$, older birds born in the east or the village were significantly more yellow than yearling birds from those areas $(P<0.001)$.

\section{PC3 (UV)}

Unlike in PC2 (see above), there were significant differences in PC3 between males and females, with male plumage reflecting significantly more in the UV part of the spectrum than female plumage $\left(F_{[1,177]}=48.5, P<0.001\right)$. Furthermore, there was a significant effect of the population of breeding on PC3 $\left(F_{[1,177]}=11.5, P<0.001\right)$. Most inter- 
Fig. 3. Mean (SE) variation in yellow (PC2) (A: yearling; B: older) and UV (PC3) (C: yearling; D: older) with respect to origin. Note that great tits (Parus major) with higher values of PC2 appear less yellow, while birds with higher values of PC3 are more UV. PC3 values have been corrected for the effects of sex and area of breeding. Immi, immigrant.
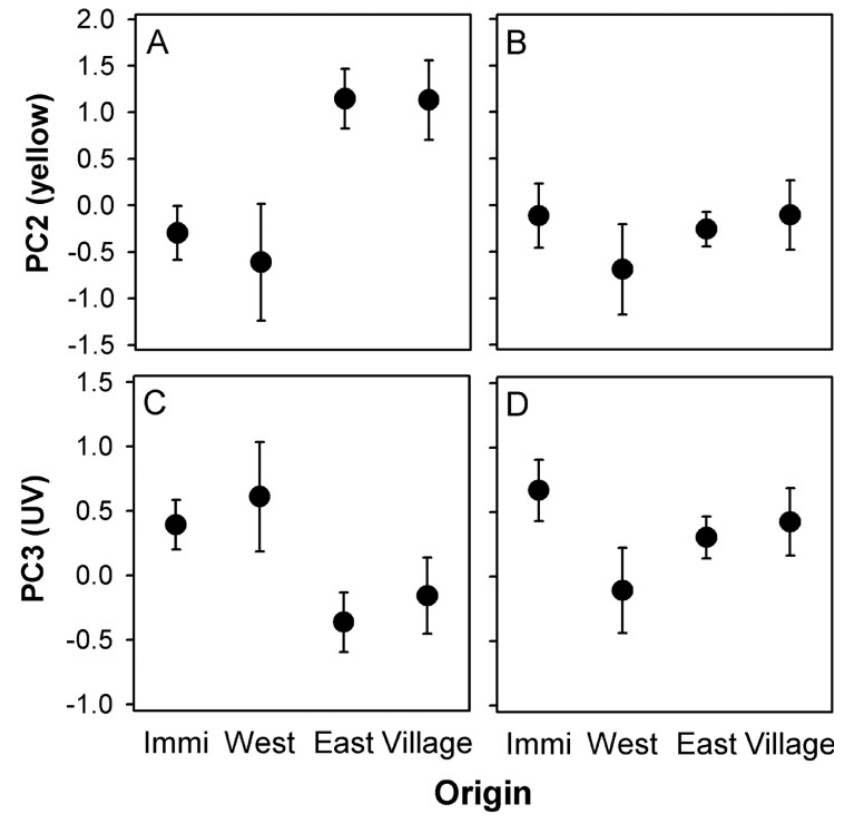

estingly, however, PC3 showed similar patterns with respect to origin as PC2 (Figs. 3C, 3D).

Just like for PC2, there was no difference between birds born in the village and birds born in the west $\left(F_{[2,177]}=\right.$ $0.27, P=0.76)$; there was also no strong evidence for a difference between birds born in the west and immigrant birds in PC3 $\left(F_{[2,179]}=1.94, P=0.15\right)$. We again found a significant difference between western and immigrant birds on the one hand, and eastern and village birds on the other, and that the size of this difference varied between yearlings and adults $\left(F_{[1,181]}=4.11, P=0.044\right)$. As was the case for PC2, there was a significant difference in the yearling birds ( $\mathrm{Tu}-$ key's honest significant difference: $P=0.034$ ) (Fig. 3C), while no such difference existed among older birds $(P=$ 1.00) (Fig. 3D).

\section{Discussion}

We found some striking differences and similarities in both pigment-based and structural components of plumage coloration with respect to origin among great tits breeding on the small island of Vlieland, at least among yearling birds. Although these phenotypic differences in coloration among birds of different origin may have a genetic basis, genetic differentiation between nearby populations is generally assumed to be prevented by the homogenizing effect of gene flow owing to dispersal. Several recent studies, however, have shown that genetic differences may exist even on a very small spatial scale (Coltman et al. 2003; Garant et al. 2005; Postma and van Noordwijk 2005). For example, it has been shown that immigrant great tits and great tits born in the western part of Vlieland have the genes for larger clutches compared with birds that are born in the eastern part of the island, which is because western birds are more closely related to immigrants than eastern birds (Postma and van Noordwijk 2005). The similarity between immigrant and western birds with respect to their breast color described here matches this genetic similarity for clutch size. Also the difference in coloration between yearling western or immigrant birds on the one hand and yearling eastern birds on the other matches the genetic difference in clutch size between these two groups of birds. The observed pattern in coloration would thus be in accordance with a genetic difference in coloration between western or immigrant birds and eastern birds.

However, whereas we were able to separate the role of genetic and environmental effects in shaping the observed patterns in clutch size (Postma and van Noordwijk 2005), we unfortunately do not have sufficient data to perform a similar analysis for the observed patterns in plumage coloration. Our finding that birds born in the east have plumage that is of a relatively less bright yellow and UV than immigrant and western birds could thus be explained by environmental differences between west and east as well. For example, parasite abundance may be higher in the eastern part of the island (Hõrak et al. 2001), or carotenoid or resource availability may be lower (Hill 1993; Hill and Montgomerie 1994; Hõrak et al. 2001). Note, however, that it is the eastern birds that are less yellow and UV, which might suggest that conditions would be worse in the east than in the west. This is in contrast with the earlier finding that birds breeding in the east have higher recruitment rates than those breeding in the west, and that birds born in the east have higher survival rates than those born in the west (Postma and van Noordwijk 2005).

The absence of a difference between birds of different origin among the older birds, of which most will have molted in their area of breeding, argues against a genetic difference between yearling great tits from the east and the village on the one hand, and western birds and immigrants on the other. It should, however, also be noted that differences between age classes within a single year are confounded by differences among cohorts. Furthermore, without data from multiple years and multiple observations on the same individual at different moments in time, it is impossible to distinguish between age effects and effects of selection. So, although the absence of an origin effect among birds born before 2003 is intriguing and deserves further attention, we can currently only speculate about possible explanations.

Irrespective of the underlying mechanisms, we have shown that differences in both structural and pigment-based components of coloration can exist at very small spatial scales, and that these differences match those found earlier for clutch size and survival. This may have a number of interesting evolutionary implications. First, if we would have been unable to distinguish birds of different origin, as is the case for the majority of studied populations, the similar patterns we found for coloration, clutch size, and survival would result in a strong association between coloration and fitness, suggesting that natural selection is acting directly on plumage coloration. Second, as individuals are by chance more likely to have a partner from the same (sub)population, ignoring systematic differences in colora- 
tion between (sub)populations will result in a correlation between the color of males and of females, which could be interpreted as evidence for assortative mating with respect to plumage coloration.

Differences in color between (sub)populations may also have important implications for sexual selection. For example, if immigrant birds differ in their appearance from local birds, this may facilitate assortative mating with respect to origin, and thereby reduce gene flow into the population (Verhulst and van Eck 1996). On the other hand, however, if their brighter yellow and UV plumage makes immigrant males more attractive to females (e.g., Hill 1991; Bennett et al. 1997), then this may in fact increase the amount of gene flow into the population. Furthermore, if immigrants are more brightly yellow and UV than local birds, yet are of similar (genetic) quality (because the price of more intensely colored plumage differs between populations), then this may undermine the reliability of plumage coloration as an honest indicator of quality (Zahavi 1975) and promote the evolution of multiple ornaments (Møller and Pomiankowski 1993).

On the whole we conclude that spatial variation in plumage coloration can exist on relatively small spatial scales, and even among birds breeding in the same area but of different origin. Irrespective of whether these color differences have an environmental or genetic basis, when not accounted for explicitly they may seriously affect, for example, estimates of selection and assortative mating. Furthermore, our results emphasize that local and immigrant birds may differ in many ways, and that many of these differences are not obvious to the human eye. These differences can play an important role in shaping gene flow and the reliability of sexually selected characters, and thereby the processes of both natural selection and sexual selection.

\section{Acknowledgements}

We are grateful to the State Forestry Commission for their permission to let us work on their property, to Barbara Tschirren for comments and discussion that greatly improved previous versions of the manuscript, to Tobias Limbourg who provided help with the spectrometer, to John Loehr for improving the English, and to multiple anonymous reviewers for critical comments. E.P. was financially supported by the Netherlands Organization for Scientific Research (ALW-NWO) and a University of New South Wales Vice-Chancellors' Postdoctoral Fellowship.

\section{References}

Abbott, J.K., Bensch, S., Gosden, T.P., and Svensson, E.I. 2008. Patterns of differentiation in a colour polymorphism and in neutral markers reveal rapid genetic changes in natural damselfly populations. Mol. Ecol. 17: 1597-1604. doi:10.1111/j.1365294X.2007.03641.x. PMID:18284565.

Andersson, M. 1994. Sexual selection. Princeton University Press, Princeton, N.J.

Arriero, E., and Fargallo, J.A. 2006. Habitat structure is associated with the expression of carotenoid-based coloration in nestling blue tits Parus caeruleus. Naturwissenschaften, 93: 173-180. doi:10.1007/s00114-006-0090-5. PMID:16508792.

Bennett, A.T.D., and Cuthill, I.C. 1994. Ultraviolet vision in birds: what is its function? Vision Res. 34(11): 1471-1478. doi:10. 1016/0042-6989(94)90149-X. PMID:8023459.
Bennett, A.T.D., Cuthill, I.C., Partridge, J.C., and Lunau, K. 1997. Ultraviolet plumage colors predict mate preferences in starlings. Proc. Natl. Acad. Sci. U.S.A. 94(16): 8618-8621. doi:10.1073/ pnas.94.16.8618. PMID:9238026.

Bensch, S., Andersson, T., and Akesson, S. 1999. Morphological and molecular variation across a migratory divide in willow warblers, Phylloscopus trochilus. Evolution, 53(6): 1925-1935. doi:10.2307/2640451.

Biard, C., Surai, P.F., and Møller, A.P. 2006. Carotenoid availability in diet and phenotype of blue and great tit nestlings. J. Exp. Biol. 209(6): 1004-1015. doi:10.1242/jeb.02089. PMID:16513926.

Biard, C., Surai, P.F., and Møller, A.P. 2007. An analysis of preand post-hatching maternal effects mediated by carotenoids in the blue tit. J. Evol. Biol. 20: 326-339. doi:10.1111/j.14209101.2006.01194.x. PMID:17210026.

Candolin, U. 2003. The use of multiple cues in mate choice. Biol. Rev. Camb. Philos. Soc. 78(4): 575-595. doi:10.1017/ S1464793103006158. PMID:14700392.

Coltman, D.W., Pilkington, J.G., and Pemberton, J.M. 2003. Finescale genetic structure in a free-living ungulate population. Mol. Ecol. 12(3): 733-742. doi:10.1046/j.1365-294X.2003.01762.x. PMID:12675828.

Crawley, M.J. 2007. The R Book. John Wiley \& Sons Ltd, Chichester, UK.

Cuthill, I.C., Bennett, A.T.D., Partridge, J.C., and Maier, E.J. 1999. Plumage reflectance and the objective assessment of avian sexual dichromatism. Am. Nat. 153(2): 183-200. doi:10.1086/ 303160.

Doucet, S.M., Shawkey, M.D., Rathburn, M.K., Mays, H.L., and Montgomerie, R. 2004. Concordant evolution of plumage colour, feather microstructure and a melanocortin receptor gene between mainland and island populations of a fairy-wren. Proc. R. Soc. Lond. B Biol. Sci. 271(1549): 1663-1670. doi:10.1098/ rspb.2004.2779.

Eaton, M.D., and Lanyon, S.M. 2003. The ubiquity of avian ultraviolet plumage reflectance. Proc. R. Soc. Lond. B Biol. Sci. 270(1525): 1721-1726. doi:10.1098/rspb.2003.2431.

Eeva, T., Lehikoinen, E., and Ronka, M. 1998. Air pollution fades the plumage of the Great Tit. Funct. Ecol. 12(4): 607-612. doi:10.1046/j.1365-2435.1998.00221.x.

Fitze, P.S., Kölliker, M., and Richner, H. 2003. Effects of common origin and common environment on nestling plumage coloration in the great tit (Parus major). Evolution, 57(1): 144-150. PMID:12643574.

Garant, D., Kruuk, L.E.B., Wilkin, T.A., McCleery, R.H., and Sheldon, B.C. 2005. Evolution driven by differential dispersal within a wild bird population. Nature (London), 433: 60-65. doi:10. 1038/nature03051. PMID:15635409.

Goodwin, T.W. 1984. The biochemistry of carotenoids. Chapman \& Hall, London, UK.

Grether, G.F., Hudon, J., and Millie, D.F. 1999. Carotenoid limitation of sexual coloration along an environmental gradient in guppies. Proc. R. Soc. Lond. B Biol. Sci. 266: 1317-1322. doi:10.1098/rspb.1999.0781.

Hadfield, J.D., and Owens, I.P.F. 2006. Strong environmental determination of a carotenoid-based plumage trait is not mediated by carotenoid availability. J. Evol. Biol. 19: 1104-1114. doi:10. 1111/j.1420-9101.2006.01095.x. PMID:16780511.

Hill, G.E. 1991. Plumage coloration is a sexually selected indicator of male quality. Nature (London), 350(6316): 337-339. doi:10. 1038/350337a0.

Hill, G.E. 1993. Geographic variation in the carotenoid plumage pigmentation of male house finches (Carpodacus mexicanus). 
Biol. J. Linn. Soc. 49(1): 63-86. doi:10.1111/j.1095-8312.1993. tb00685.x.

Hill, G.E., and McCraw, K.J. 2006. Bird coloration. Vol. 2. Function and evolution. Harvard University Press, Cambridge, Mass.

Hill, G.E., and Montgomerie, R. 1994. Plumage color signals nutritional condition in the house finch. Proc. R. Soc. Lond. B Biol. Sci. 258(1351): 47-52. doi:10.1098/rspb.1994.0140.

Hoekstra, H.E., Krenz, J.G., and Nachman, M.W. 2005. Local adaptation in the rock pocket mouse (Chaetodipus intermedius): natural selection and phylogenetic history of populations. Heredity, 94(2): 217-228. doi:10.1038/sj.hdy.6800600. PMID:15523507.

Hõrak, P., Vellau, H., Ots, I., and Møller, A.P. 2000. Growth conditions affect carotenoid-based plumage coloration of great tit nestlings. Naturwissenschaften, 87(10): 460-464. doi:10.1007/ s001140050759. PMID:11129946.

Hõrak, P., Ots, I., Vellau, H., Spottiswoode, C., and Møller, A.P. 2001. Carotenoid-based plumage coloration reflects hemoparasite infection and local survival in breeding great tits. Oecologia (Berl.), 126(2): 166-173. doi:10.1007/s004420000513.

Houde, A.E. 1987. Mate choice based upon naturally occurring color pattern variation in a guppy population. Evolution, 41(1): 1-10. doi:10.2307/2408968.

Houde, A.E., and Endler, J.A. 1990. Correlated evolution of female mating preferences and male color patterns in the guppy Poecilia reticulata. Science, 248(4961): 1405-1408. doi:10.1126/ science.248.4961.1405. PMID:17747527.

Johnsen, A., Delhey, K., Andersson, S., and Kempenaers, B. 2003. Plumage colour in nestling blue tits: sexual dichromatism, condition dependence and genetic effects. Proc. R. Soc. Lond. B Biol. Sci. 270: 1263-1270. doi:10.1098/rspb.2003.2375.

Keyser, A.J., and Hill, G.E. 2000. Structurally based plumage coloration is an honest signal of quality in male blue grosbeaks. Behav. Ecol. 11(2): 202-209. doi:10.1093/beheco/11.2.202.

Kodric-Brown, A., and Johnson, S.C. 2002. Ultraviolet reflectance patterns of male guppies enhance their attractiveness to females. Anim. Behav. 63: 391-396. doi:10.1006/anbe.2001.1917.

Lessells, C.M., and Boag, P.T. 1987. Unrepeatable repeatabilities: a common mistake. Auk, 104: 116-121.

McGraw, J.B. 2006. Mechanics of carotenoid-based coloration. In Bird coloration. Vol. 1. Mechanisms and measurements. Edited by G.E. Hill and J.B. McGraw. Harvard University Press, Cambridge, Mass. pp. 177-242.

Milinski, M., and Bakker, T.C.M. 1990. Female sticklebacks use male coloration in mate choice and hence avoid parasitized males. Nature (London), 344(6264): 330-333. doi:10.1038/ 344330a0.

Møller, A.P., and Pomiankowski, A. 1993. Why have birds got multiple sexual ornaments. Behav. Ecol. Sociobiol. 32(3): 167176. doi:10.1007/BF00173774.

Olson, V.A., and Owens, I.P.F. 1998. Costly sexual signals: are carotenoids rare, risky or required? Trends Ecol. Evol. 13(12): 510-514. doi:10.1016/S0169-5347(98)01484-0.

Olsson, M. 1994. Nuptial coloration in the sand lizard, Lacerta agilis: an intra-sexually selected cue to fighting ability. Anim. Behav. 48(3): 607-613. doi:10.1006/anbe.1994.1280.

Örnborg, J., Andersson, S., Griffith, S.C., and Sheldon, B.C. 2002. Seasonal changes in a ultraviolet structural colour signal in blue tits, Parus caeruleus. Biol. J. Linn. Soc. 76(2): 237-245.
Partali, V., Liaaen-Jensen, S., Slagsvold, T., and Lifjeld, J.T. 1987. Carotenoids in food chain studies - II. The food chain of Parus spp. monitored by carotenoid analysis. Comp. Biochem. Physiol. B, 87(4): 885-888. doi:10.1016/0305-0491(87)90408-1.

Postma, E., and van Noordwijk, A.J. 2005. Gene flow maintains a large genetic difference in clutch size at a small spatial scale. Nature (London), 433: 65-68. doi:10.1038/nature03083. PMID:15635410.

Prum, R.O., Andersson, S., and Torres, R.H. 2003. Coherent scattering of ultraviolet light by avian feather barbs. Auk, 120(1): 163-170. doi:10.1642/0004-8038(2003)120[0163:CSOULB]2.0. $\mathrm{CO} ; 2$.

R Development Core Team. 2008. R: a language and environment for statistical computing. Version 2.7.1. R Foundation for Statistical Computing, Vienna, Austria. Available from http://www. R-project.org.

Rosenblum, E.B. 2006. Convergent evolution and divergent selection: lizards at the White Sands ecotone. Am. Nat. 167(1): 115. doi:10.1086/498397. PMID:16475095.

Saks, L., McGraw, K., and Hõrak, P. 2003a. How feather colour reflects its carotenoid content. Funct. Ecol. 17(4): 555-561. doi:10.1046/j.1365-2435.2003.00765.x.

Saks, L., Ots, I., and Hõrak, P. 2003b. Carotenoid-based plumage coloration of male greenfinches reflects health and immunocompetence. Oecologia (Berl.), 134(3): 301-307.

Senar, J.C., Figuerola, J., and Pascual, J. 2002. Brighter yellow blue tits make better parents. Proc. R. Soc. Lond. B Biol. Sci. 269(1488): 257-261. doi:10.1098/rspb.2001.1882.

Shawkey, M.D., and Hill, G.E. 2005. Carotenoids need structural colours to shine. Biol. Lett. 1(2): 121-124. doi:10.1098/rsbl. 2004.0289. PMID:17148144.

Shawkey, M.D., Pillai, S.R., Hill, G.E., Siefferman, L.M., and Roberts, S.R. 2007. Bacteria as an agent for change in structural plumage color: correlational and experimental evidence. Am. Nat. 169(1): S112-S121. doi:10.1086/510100.

Sinervo, B., and Lively, C.M. 1996. The rock-paper-scissors game and the evolution of alternative male strategies. Nature (London), 380(6571): 240-243. doi:10.1038/380240a0.

Slagsvold, T., and Lifjeld, J.T. 1985. Variation in plumage colour of the Great Tit Parus major in relation to habitat, season and food. J. Zool. Ser. A, 206: 321-328.

Stuart-Fox, D.M., Moussalli, A., Johnston, G.R., and Owens, I.P.F. 2004. Evolution of color variation in dragon lizards: quantitative tests of the role of crypsis and local adaptation. Evolution, 58(7): 1549-1559. PMID:15341157.

Tschirren, B., Fitze, P.S., and Richner, H. 2003. Proximate mechanisms of variation in the carotenoid-based plumage coloration of nestling great tits (Parus major L.). J. Evol. Biol. 16: 91-100. doi:10.1046/j.1420-9101.2003.00483.x. PMID:14635884.

van Noordwijk, A.J., van Balen, J.H., and Scharloo, W. 1981. Genetic and environmental variation in clutch size of the great tit (Parus major). Neth. J. Zool. 31(2): 342-372.

Verhulst, S., and van Eck, H.M. 1996. Gene flow and immigration rate in an island population of great tits. J. Evol. Biol. 9(6): 771-782. doi:10.1046/j.1420-9101.1996.9060771.x.

Zahavi, A. 1975. Mate selection — a selection for a handicap. J. Theor. Biol. 53: 205-214. doi:10.1016/0022-5193(75)90111-3. PMID:1195756. 